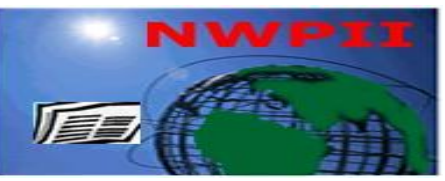

American Journal of Biomedical Sciences

ISSN: 1937-9080

nwpii.com/ajbms

\title{
Genetic Causes of Interstitial Lung Disease in Children
}

\author{
Yao Yao, $\mathrm{MD}^{1 \& 2}$, Lael M. Yonker, $\mathrm{MD}^{2}$ T. Bernard Kinane, $\mathrm{MD}^{2^{*}}$ Baoping $\mathrm{Xu}, \mathrm{MD}^{1^{*}}$
}

${ }^{1}$ Department of Pulmonary Medicine, Beijing Children's Hospital, Beijing, PR China

${ }^{2}$ Massachusetts General Hospital, Department of Pediatrics, Pulmonary Division, Boston, MA, USA

*Corresponding author:

Bernard Kinane

Department of Pediatrics, Pulmonary Division

Massachusetts General Hospital

Boston, MA, 02114, USA

Email: Kinane.Bernard@mgh.harvard.edu

Baoping Xu

Department of Pulmonary

Beijing Children's Hospital

Capital Medical University

Beijing 100045, PR China

Email: xubaoping@bch.com.cn

Received: 24 October 2014; | Revised: 21 November 2014; | Accepted: 23 December 2014

\begin{abstract}
Interstitial lung diseases (ILDs) occur through out childhood and adult life. In neonates and infants, defects in lung development and growth and defects in surfactant production and function are common features with the environmental factors being less important. For older children, genetic background combined with environmental exposure is central to the pathophysiology of ILD. In adults, environmental exposure becomes more critical to mechanism of disease with genetic background becoming less essential. Thus ILDs are often multifactorial in origin but recently molecular genetic defects have been described, especially in children. Thus, genetic testing is a non-invasive investigation that is likely to identify the genetic underpinning of childhood interstitial lung diseases (chILD). This is likely to provide insights into the mechanism of disease, which that may be helpful for treatment and defining the prognosis. This review summarizes genetic defects that can lead to ILDs, and highlights the recent advances in several kinds of chILD.
\end{abstract}

Keywords: Interstitial lung disease; Children; genetics. 


\section{Introduction}

Interstitial lung disease (ILD) consists of a diverse group of disorders that involve the pulmonary parenchyma and interfere with gas exchange [1]. ILD is rare in children, but is associated with high mortality [2] and poor prognosis [3]. In children, ILD although less frequent, comprises a broader spectrum of disorders with a more variable clinical course compared to adults. Adult patterns of disease are well understood. Usual interstitial pneumonia (UIP) the pathologic correlate of idiopathic pulmonary fibrosis (IPF) is the most common ILD in adults but has yet to be described in any pediatric case [4]. Nonspecific interstitial pneumonia (NSIP), although frequent in the adult population might in frequently occur in children. IPF/UIP and NSIP closely mimic each other clinically but NSIP has a far better outcome. There is some overlap in the histological pathological patterns of ILD in adults; Whether NSIP is a truly separate and distinct entity of IPF remains not to be established [5].

Children's Interstitial Lung Diseases (chILDs) are a broad spectrum of disorders with a different and more variable clinical course [6]. chILD includes unique disease entities like pulmonary interstitial glycogenosis [7], the neuroendocrine cell hyperplasia of infancy [8] and the genetic disorders of surfactant metabolism. Even in children different histologic patterns are observed in older children [9]. Accordingly classification has been difficult. There have been many different approaches to classify chILDs; in 2002 a classification that integrated clinical investigation, radiography and pathology (CRP) was established for ILD [10]. Important insights of this classification include the role of defects in lung development and surfactant metabolism in the pathophysiology of chILDs [11]. Even within chILDs similar diseases have different prognoses. The American Thoracic Society's practice guidelines lead to the development of an even more coherent classification of ILDs for infant [12]. This builds on the former classification that was proposed by the chILDs Research Network [4]. This classification scheme includes two main categories: "disorders more prevalent in infancy" and "disorders not specific to infancy." Some disorders present predominantly in infancy, but may also present later in childhood or even adulthood; likewise conditions that are more common in older children and adults, can present in infancy.

Heterogenetic clinical features, genetic background and environmental interaction have made chILD difficult to classify. An understanding of how genetic factors and environmental exposures interact in individuals to alter normal biological function is required to advance our understanding of these conditions. Genetic underpinning is important for children. With the advent of modern genetics testing, a classification that is based upon underlying mechanisms of disease is possible which also allows for counseling families concerning recurrence risks and prediction of natural history. The biological/genetic data may contribute to a better understanding of the etiology of the chILD. In this review we highlight the genetic basis of disease as well as how infectious diseases can cause ILD type diseases

\section{Disorders more prevalent in infancy}

\subsection{The disorders of development and growth of lung}

The interaction between the lung bud, mesenchyme and epithelium influences the prenatal and postnatal development and growth of the lung. Any disturbance during this process may result in a mal-development of the lung. This pattern is well illustrated in some specific forms of ILD more prevalent in infancy such as alveolar capillary dysplasia, a misalignment of the pulmonary veins (ACD/MPV), and bronchopulmonary dysplasia.

\subsubsection{Alveolar capillary dysplasia}

Alveolar capillary dysplasia with misalignment of the pulmonary veins (ACD/MPV) is a rare, fatal developmental lung disorder of neonates and infants with an inadequate development of the pulmonary capillary bed. Affected infants typically present with fulminant symptoms. 
Stankiewicz and colleagues reported that six different-sized overlapping microdeletions encompassing the Forkhead box protein (FOX) transcription factor gene cluster in chromosome 16q24.1q24.2 in patients with ACD/MPV [13]. Within this cluster a number of candidate genes were identified but ultimately Forkhead box protein $\mathrm{F} 1$ (FOXF1) was confirmed to be essential as four different heterozygous mutations (frameshift, nonsense, and no-stop) were described in this gene. In about $40 \%$ of ACD/MPV cases a mutation or deletion in FOXF1 gene can be identified. The molecular pathogenesis of FOXF1 in ACD/MPV remains unclear. Studies in humans and mice have revealed that the FOXF1 protein is involved in sonic hedgehog signaling and in turn sonic signally is important for vascular signaling. These signaling cascades must somehow be altered to result in ACD/MPV.

The spectrum of disease is now being appreciated. Rare reports with late onset or mild symptoms have begun to emerge in infancy $[14,15]$. Also from pedigree analyses of ACD/MPV patients' families, ACD/MPV have both autosomal dominant and recessive patterns of inheritance [16]. FOXF1 mutations or deletions do not account for all of the cases, thus other genes are possible. Sonic hedgehog signaling proteins are attractive candidates genes.

Genetics and gene expression studies are providing insights into the molecular pathophysiology of ACD/MPV. Sen et al reported that by comparing transcriptomes of human ACD/MPV lungs with control lungs using expression arrays several genes and pathways that were involved in lung development, angiogenesis, and in pulmonary hypertension development were deregulated. Similarly transcriptional changes were found in the lungs of the postnatal day $0.5 F_{0 x f 1^{+/-}}$mice when compared to their wild-type littermate controls. Dysregulatin of 14 genes (COL15A1, COL18A1, COL6A2, ESM1, FSCN1, GRINA, IGFBP3, IL1B， MALL， NOS3， RASL11B， MATN2, PRKCDBP, and SIRPA) was a common for lungs from humans with ACD/MPV and from Foxf $1^{+/-}$ mice [17]. Ren and collaborators described the role of FOXF1 in the development of embryonic vasculature. The loss of endothelial FOXF1 induced a profound reduction in the expression of several endothelial specific genes encoding including VEGFR1, VEGFR2 and PECAM [18]. Tiozzoet et al found that patients with ACD had decreased expression of the phosphatase and tensin homolog, PTEN. This is a known tumor suppressor gene that controlling that controls cell cycle genes thus is likely to be important for stem/progenitor cell proliferation and differentiation. Mesodermal PTEN inactivation leads to alveolar capillary dysplasia-like phenotype [19].

With advances in technology, the identification of new candidate genes is possible. Next-generation sequencing technologies enabled identification of several new genes for sequencing whole genome and exome. Sequencing ACD/MPV samples from pedigrees and the family members showing autosomal recessive pattern inheritance will provide new genetic insights.

\subsubsection{Bronchopulmonary dysplasia}

Bronchopulmonary dysplasia (BPD) is a post-natal growth abnormality, which is the most common chronic lung disease of infants. BPD is chronic lung disease of prematurity mainly affecting preterm infants that are born at 24-28 weeks of gestation [20] or low birth weight. However, a few term infants with early postnatal lung injury may also show the changes of BPD; likewise not all the preterm infants with postnatal lung injury may develop BPD. Therefore susceptibility to BPD is in part inherited. Likewise affected twins have been described, which suggests a genetic contribution to BPD. [21-23]. On the basis of current understanding of $\mathrm{BPD}$, investigators have identified backgrounds modifying gene via SNP analysis. Broad categories of genes were found to be important including those with the roles in lung development, surfactant metabolism, and regulation of inflammation. The candidate genes included tumor necrosis factor (TNF), angiotensin converting enzyme (ACE), vascular endothelial growth factor (VEGF), transforming growth factor alpha (TGF $\alpha$ ), and toll-like 
receptor, mannose-binding lectin (MBL), interleukin-18 (IL-18), Superoxide dismutases (SOD), The cytokine macrophage migration inhibitory factor (MIF), Matrix metalloproteinase (MMP), dystroglycan 1 (dystrophin-associated glycoprotein 1) (DAG1).

Ryckman KK et al found that a allele of rs4351 in the angiotensin-converting enzyme (ACE) gene was over-transmitted from parents to very preterm birth (gestational age $<32$ weeks) offspring with BPD which suggest an association with an increased risk of $\mathrm{BPD}, \mathrm{OR}=4.3$ [24]. Mailaparambil B. et al reported that three SNPs in TNFa ( $\mathrm{rs}=1799724)$, VEGFA ( $\mathrm{rs}=699947)$, and TLR10 ( $\mathrm{rs}=11096955)$ in $47 / 155$ infants (gestational age $<=28$ weeks), who developed moderate or severe BPD. Meanwhile TNF $\alpha$ and VEGFA showed also association with BPD in haplotype analyses [25].

Stisti B. et al reported that SOD3 gene, that encodes extracellular superoxide dismutase (rs2536512) was associated with a reduced risk of $\mathrm{BPD}, \mathrm{OR}=0.49$. SOD2 (rs4880 and rs5746136) and SOD3 (rs8192287, rs2536512 and rs1799895) with haplotype analyses showed associations for BPD [26].

In a study with 269 infants who were born with GA < 30 weeks, Lavoie, et al found that the TLR4 polymorphisms Asp299Gly (rs4986790) and Thr399Ile (rs4986791) were associated with BPD [27]. Sampath et al reported that the TLR5 (g. 1174C $>$ T) variant was associated with BPD $(\mathrm{P}=0.03) \quad \mathrm{OR}=2.6 \quad(1.1-6.0)$ and severe $\mathrm{BPD}$ $(\mathrm{P}=0.004) \mathrm{OR}=3.8$ (1.5-9.9) [28].

On the basis of murine work, which identified the association between macrophage migration inhibitory factor (MIF) and fetal lung development [29], Prencipe $\mathrm{G}$ et al found that the $\mathrm{MIF}-173 * \mathrm{C}$ allele was associated with a lower incidence of BPD (OR, 0.2) [30].

Floros et al found that SNPs in the IL-18 receptor accessory protein (IL-18RAP) (rs3771150) and IL-18 receptor 1 (IL-18R1) (rs3771171) were associated in Africa Americas with mild/moderate/severe BPD [31]. Krueger et al found a strong association of SNPs in IL-18 with preterm birth $(\mathrm{p}<0.001)$. They haven't found this association with premature birth and infants born at term as controls [32].
Hadchouel A et al reported that SNPS in MMP16 C/T (rs2664352) and MMP16 A/ G (rs2664349) were associated with protection of BPD [33].

Dystroglycan (DG) with highly expression in the epithelial cell where it supports morphogenesis, adhesion and wound repair, which is essential to recovery from hyaline membrane disease. Concolino $\mathrm{P}$ et al found that one SNP in dystroglycan 1 (dystrophin-associated lycoprotein 1) (DAG1) (N494H) was associated with BPD [34]. Extending the theme where inflammation is important in BPD Hilgendorff A et al found that two SNPs of mannose-binding lectin gene (rs1800450, codon 54) and (rs7096206, -221 G>C) were associated with development of BPD [35].

The studies have a number of limitations. Unfortunately many studies relied on single clinical populations have variable severity of patients. Also the role of prematurity from other genetic factors was difficult to delineate. Although many genes have been investigated with most studies investigating how individual gene were responsible. These studies are difficult to interpret, as statistical analysis is difficult. However on the whole, general themes have been established where genetic modification in surfactant genes, immune genes and developmental genes contribute to BPD.

\subsection{Surfactant dysfunction disorder}

Specific genetic causes for Surfactant dysfunction disorder in chILDs include deletions or mutations in genes encoding proteins involved surfactant production and metabolism including surfactant protein-B (SP-B), surfactant protein-C (SP-C), ATP-binding cassette, sub-family A, member 3 (ABCA3), thyroid transcription factor 1 (TTF1) and granulocyte-macrophage colonystimulating factor (GM-CSF) receptor. GM-CSF receptor defect is discussed in this category, as it is important for surfactant catabolism. Approximately $25 \%$ of infants with severe refractory ILD have a mutation in these genes [36]. 


\subsubsection{Surfactant Protein-B gene}

Surfactant protein-B (SP-B) is encoded by a single gene (SFTPB) on human chromosome 2 . Proteolytic cleavage of a larger precursor protein (pro SP-B) yields the 79 amino acid mature SP-B protein found in the airspaces. Mutations in SP-B deficiency (OMIM \#265120) are usually lethal over the first few days of life [37]. SP-B deficiency is inherited in an autosomal recessive pattern. The first and most common mutation identified involves a substitution of three bases (GAA) for one (C) in codon 121 of the SP-B mRNA, located in exon 4 of the SP-B gene, leading to a net insertion of 2 bases, and is termed 121 ins 2 which is the most frequently found SFTPB mutation [38]. And another mutation is a single base $\mathrm{T}$ deletion at nucleotide 1553 in exon 4. The single base (T) deletion at nucleotide 1553 (1553delT) shifts the reading frame at amino acid 122 (122delT) and creates a premature termination codon at amino acid 214 in exon 6 [48]. Rare cases have been reported where patient have a milder course, and survived for months to years. These patients usually have mutations that allow for some SP-B production [39].

\subsubsection{Surfactant Protein-C gene}

Surfactant Protein-C (SP-C) deficiency (OMIM\#610913) results from a mutation of surfactant Protein-C gene (SFTPC), which is located on chromosome 8 (8p21.3). SP-C is secreted by alveolar type II cells and plays a critical role in surfactant homeostasis [40]. Heterozygous mutations in SFTPC are disease causing, thus are inherited in a dominant pattern. Mutations in SFTPC were first recognized in 2001 by Nogee et al. The age-of-onset and severity of symptoms of individuals with SFTPC mutations differ from severe RDS in neonates to idiopathic pulmonary fibrosis in adult; indeed some adults with mutations in SFTPC may be asymptomatic [41, 42]. Various SFTPC mutations have been identified and one mutation has been found in unrelated families [43, 44]. Little is known about long-term health issues in this population. Yonker L. et al (unpublished) reports the association of a SP-C mutation developed lung adenocarcinoma; thus raising concerns about the risk of developing cancer.

\subsubsection{ATP-binding cassette, sub-family A, member 3}

ATP-Binding Cassette subfamily A Member 3 (ABCA3) is a transmembrane protein found on the membrane that surrounding lamellar bodies. The ABCA3 protein transports phospholipids into the lamellar bodies in order to form surfactant. Recessive ABCA3 mutations causes lethal neonatal respiratory failure and childhood interstitial lung disease [45]. The clinical characteristics of patients with ABCA3 deficiency is much more variable from neonates with respiratory failure to heterozygous $\mathrm{ABCA} 3$ mutation carriers with minimal lung disease [46]. Most ABCA3 mutations are private. Wambach et al. found that a having a single ABCA 3 mutation significantly increases the risk for respiratory distress syndrome (RDS) in term or late preterm infants, without ILD [47]. Bullard JE et al investigated that patients with desquamative interstitial pneumonitis had missense ABCA3 mutation $(\mathrm{E} 292 \mathrm{~V})$, which might be a cause of pediatric interstitial lung disease [48].

Hallik $M$ et al reported that two novel compound heterozygous mutations (Asp507del CA Ter 508 mutation in exon 13 and Asp696Asn (D696N) in exon 17) of the ABCA3 gene were found in a pair of siblings, resulting in very different phenotypes. The girl developed respiratory distress syndrome at birth and her older brother with the same genotype had no manifestations of ILD and the CT of the lungs is normal [49].

Genotype-phenotype correlations exist for homozygous or compound heterozygous mutations in ABCA3. Kitazawa et al reported that two brothers with ILD had novel compound heterozygous mutations in the coding exons of ABCA3, thus novel changes are likely [50]. On the whole, frameshift or nonsense ABCA3 mutations are predictive of neonatal presentation and poor outcome, whereas missense, splice site, and in-frame INDELs are less reliably associated with a poorer outcome [51]. Also the phenotypic expression of an ABCA3 mutation might be altered by a virus infection. It reported that Respiratory syncytial virus (RSV) infection of cells harboring ABCA3 mutations resulted in a 
morphologic shift to a mesenchymal phenotype, thus increasing the risk of fibrosis. RSV infections also potentiated ABCA3 mutationsinduce loss of epithelial cell differentiation in Alveolar Type II Epithelial Cell (ATII) and the impairment of epithelial function [52].

\subsubsection{Thyroid transcription factor 1}

As a member of the homeobox family of transcription factors, Thyroid transcription factor 1 (TTF1), also known as Nkx2.1 or TITF1, located on the long arm of chromosome 14 (14q13.3), is critically important for the expression of multiple genes important in production and function of SP-A, SP-B, SP-C, and ABCA3. The phenotype of TTF1 haploinsufficiency includes hypothyroidism, neurological manifestations particularly choreoathetoid movements, and pulmonary disease ranging from neonatal RDS to chronic respiratory symptoms in childhood [53]. But whether TTF1 mutations can result in a phenotype with only pulmonary manifestations is unknown. The relationship between TTF1 haploinsufficiency and production of surfactant warrants further investigation [53]. How mutation in this gene leads to phenotypical changes in a number of different systems is being investigated. Carre et al described five new mutations of TTF1 include three new heterozygous missense mutations (L176V, P202L, Q210P), a splice site mutation (376-2 A to G), and one deletion of TTF1 at 14q13. The majority of affected patients display neurological and/or thyroidal problems but the lung disease although less frequent was responsible for a considerable mortality [54].

Hamvas A et al identified 16 individuals with heterozygous missense, nonsense, and frameshift mutations and five individuals with heterozygous, whole-gene deletions of TTF1. Twelve individuals $(57 \%)$ had the full triad of neurologic, thyroid, and respiratory manifestations, but five $(24 \%)$ had only pulmonary symptoms [55]. Role of TTF1 in lung was thought to be related to surfactant metabolism. Young LR et al reported that a 7 months infant diagnosed as Neuroendocrine Cell Hyperplasia of Infancy (NEHI) had a TTF1 mutation (c.572 G.T, p.Arg191Leu). Her mother, an aunt, an uncle, and two first cousins had failure to thrive in infancy and chronic respiratory symptoms that improved with age. They were heterozygous for a missense mutation in codon 191 (c.572 G.T, p.Arg191Leu). None of these individuals have thyroid disease or movement disorders. Three other family unaffected members were also found to be heterozygous for the mutation. Thus a mutation in TTF1 is associated with familial NEHI [56].

\subsubsection{GM-CSF Deficiency}

GM-CSF is a critical regulator of surfactant catabolism in alveolar macrophages [57]. The presence of neutralizing antibodies to GM-CSF or the defect of GM-CSF receptor, leading to impairment of alveolar macrophage development and failure of the macrophages to properly catabolize surfactant can cause pulmonary alveolar proteinosis (PAP) [58]. PAP has an insidious onset in older children and adult and slowly progresses. Genetic defects in the gene encoding the $\alpha$ chain $(C S F 2 R A)$ located in the pseudoautosomal region of the $\mathrm{X}$ chromosome were as a cause for PAP in children [59]. Suzuki et al indicated that GM-CSF is required for phenotypic determination of alveolar macrophages; thus GM-CSF is required to recruit marophages to airway to clear surfactant [60].

\subsection{Unknown etiology}

\section{Pulmonary interstitial glycogenosis}

Pulmonary interstitial glycogenosis (PIG) is the diffuse accumulation of mesenchymal cells in the alveolar interstitium. These small cells have are rich monoparticulate glycogen. PIG presents as respiratory distress at or near birth in a neonate [61]. PIG can be associated with congenital heart disease and lung growth abnormalities suggesting that it is defect in development with failure of clearance of mesenchymal cells [62]. Ross, et al reported a patient with PIG who was ultimately diagnosed Noonan Syndrome; this patient had a heterozygous G60A mutation in Tyrosine-protein phosphatase non-receptor type 11 (PTPN11) suggesting that developmental genes may be important in the pathophysiology of this disease [63]. 


\section{Disorders not specific to infancy}

These disorders include disorders of the normal host, aspiration syndromes, bronchiolitis obliterans (BO), hypersensitivity pneumonitis, disorders of the immunocompromised host, disorders related to systemic disease processes, disorders masquerading as interstitial disease. In this part we focus on post-infectious bronchiolitis obliterans.

\section{Post-infectious bronchiolitis obliterans}

The susceptibility to develop post-infectious bronchiolitis obliterans (BO) seems to be associated with the ethnic background of patients and their host immunological response to the pathogens. A number of respiratory viruses, especially adenovirus (AV), have been associated with severe lung injury that can lead to bronchiolitis obliterans. During 1965, an epidemic of adenovirus type 21 infections occurred in Auckland. Some children from a particular background developed widespread bronchiectasis and features of BO [64]. For unclear reasons, post-infectious $\mathrm{BO}$ seems to occur more frequently in some races $[65,66]$. Moreover in the same race not all the patients with high risk would develop post-infectious BO and even the patients with post-infectious BO have the various severities. Thus, genetic factors may play a role in that the prevalence of $\mathrm{BO}$. Only one study found that HLA- DQB $1 * 0302$, an antigen highly represented in Amerindians, indigenous people mainly found in South America, was associated with an increased risk of $\mathrm{BO}$ in children [67]. $\mathrm{BO}$ is a common feature after lung transplantation and a protein called KL-6, a protein normally expressed activated pulmonary epithelial cells, is increased in the serum of lung transplant patients who develop BO [68]. Understanding the important genetic contributions $\mathrm{BO}$ development will provide true insight into BO development, which will have widespread implications.

\section{Summary}

Till now the etiologies of some disorders of chILDs remain unclear. chILD is still considered as a big issue for pediatric pulmonologist although numerous advances have been made in the past decade in understanding the underlying causes of ILD. The genetic test as a noninvasive approach may facilitate the diagnosis and treatment of chILD. Likewise such testing will allow for counseling families concerning recurrence risks.

\section{References}

1. Bolliger CT CU.; du Bois RM.; Egan JJ. Diffuse parenchymal lung disease, Cape Town: Karger, 2007.

2. Dinwiddie R.; Sharief N.; Crawford O. Idiopathic interstitial pneumonitis in children: a national survey in the United Kingdom and Ireland, Pediatr Pulmonol, 2002, 34(1): 23-9. DOI: 10.1002/ppul.10125

3. Fan LL.; Kozinetz CA. Factors influencing survival in children with chronic interstitial lung disease, Am J Respir Crit Care Med, 1997, $156(3$ Pt 1): 939-42. DOI: 10.1164/ajrccm.156.3.9703051

4. Deutsch GH.; Young L. R.; Deterding R. R.; Fan L. L.; Dell S. D.; Bean J. A.; Brody A. S.; Nogee L. M.; Trapnell B. C.; Langston C.; and the Pathology Cooperative Group:, Albright E. A.; Askin F. B.; Baker P.; Chou P. M.; Cool C. M.; Coventry S. C.; Cutz E.; Davis M. M.; Dishop M. K.; Galambos C.; Patterson K.; Travis W. D.; Wert S. E.; White F. V.; and on behalf of the ChILD Research Co-operative. Diffuse Lung Disease in Young Children Application of a Novel Classification Scheme, Am J Respir Crit Care Med, 176(11): 1120-1128. DOI: 10.1164/rccm.200703-393OC

5. Yang IV.; Burch LH.; Steele MP.; Savov JD.; Hollingsworth JW.; McElvania-Tekippe E.; Berman KG.; Speer MC.; Sporn TA.; Brown KK.; Schwarz MI.; Schwartz DA. 
Gene expression profiling of familial and sporadic interstitial pneumonia, Am J Respir Crit Care Med, 2007, 175(1): 45-54. DOI: 10.1164/rccm.200601-062OC

6. Fan LL.; Langston C. Pediatric interstitial lung disease: children are not small adults, Am J Respir Crit Care Med 2002, 165(11):1466-7. DOI: $\underline{10.1164 / \mathrm{rccm} .2204012}$

7. Langston $\mathrm{C} 1$; Dishop MK. Diffuse lung disease in infancy: a proposed classification applied to 259 diagnostic biopsies, Pediatr Dev Pathol, 2009, 12(6):421-37. DOI: 10.2350/08-11-0559.1

8. Popler J1.; Wagner BD.; Tarro HL.; Accurso FJ.; Deterding RR. Bronchoalveolar lavage fluid cytokine profiles in neuroendocrine cell hyperplasia of infancy and follicular bronchiolitis, Orphanet J Rare Dis, 2013, 11;8:175.

9. Bush A.; Nicholson AG. Paediatric interstitial lung disease, European Respiratory Society, 2009.

10. Travis WD.; King T.; Bateman ED.; Lynch DA.; Capron F.; Center M.; Colby TV.; Cordier JF.; duBois RM.; Galvin JR. ATS/ERS International multidisciplinary consensus classification of idiopathic interstitial pneumonia, Am J Respir Crit Care Med, 2002, 165: 277-304.

11. Whitsett J. A lungful of transcription factors, Nature Genetics, 1998, 20:7-8. DOI: $\underline{10.1038 / 1654}$

12. Kurland G.; Deterding R. R.; Hagood J. S.; Young L. R., Brody A. S.; Castile R. G.; Dell S.; Fan L. L.; Hamvas A.; Hilman B. C.; Langston C.; Nogee L. M.; Redding G. $\mathrm{J}$; on behalf of the American Thoracic Society Committee on Childhood Interstitial Lung Disease (chILD) and the chILD Research Network. An Official American Thoracic Society Clinical Practice Guideline: Classification, Evaluation, and Management of Childhood Interstitial Lung Disease in Infancy, Am J Respir Crit Care Med, 2013; 188(3): 376-394. DOI: 10.1164/rccm.201305-0923ST

13. Stankiewicz P.; Sen P.; Bhatt SS.; Storer M.; Xia Z.; Bejjani BA.; Ou Z.; Wiszniewska J.;
Driscoll DJ.; Maisenbacher MK.; Bolivar J.; Bauer M.; Zackai EH.; McDonaldMcGinn D.; Nowaczyk MM.; Murray M.; Hustead V.; Mascotti K.; Schultz R.; Hallam L.; McRae D.; Nicholson AG.; Newbury R.; Durham-O'Donnell J.; Knight G.; Kini U.; Shaikh TH.; Martin V.; Tyreman M.; Simonic I.; Willatt L.; Paterson J.; Mehta S.; Rajan D.; Fitzgerald T.; Gribble S.; Prigmore E.; Patel A.; Shaffer LG.; Carter NP.; Cheung SW.; Langston C.; ShawSmith C. Genomic and genic deletions of the fox gene cluster on 16q24.1 and inactivating mutations of foxf1 cause alveolar capillary dysplasia and other malformations. American journal of human genetics, Am J Hum Genet, 2009; 84(6): 780-791. DOI: 10.1164/rccm.201305-0923ST

14. Shankar V.; Haque A.; Johnson J.; Pietsch J. Late presentation of alveolar capillary dysplasia in an infant, Pediatr Crit Care Med, 2006, 7(2):177-9. DOI: 10.1097/01.PCC.0000202570.58016.67

15. Ahmed S.; Ackerman V.; Faught P.; Langston C. Profound hypox- emia and pulmonary hypertension in a 7-month-old infant: late presentation of alveolar capillary dysplasia, Pediatr Crit Care Med, 2008, 9(6):e43-6. DOI: 10.1097/PCC.0b013e31818e383e

16. Sen P.; Thakur N.; Stockton DW.; Langston C.; Bejjani BA. Expanding the phenotype of alveolar capillary dysplasia (ACD), J Pediatr, 2004, 145(5):646-51. DOI: 10.1016/j.jpeds.2004.06.081

17. Sen P.; Dharmadhikari AV.; Majewski T.; Mohammad MA.; Kalin TV.; Zabielska J.; Ren X.; Bray M.; Brown HM.; Welty S.; Thevananther S.; Langston C.; Szafranski P.; Justice MJ.; Kalinichenko VV.; Gambin A.; Belmont J.; Stankiewicz P. Comparative analyses of lung transcriptomes in patients with alveolar capillary dysplasia with misalignment of pulmonary veins and in foxf1 heterozygous knockout mice, PLoS One. 2014, 9(4): e94390. DOI: 10.1371/journal.pone.0094390

18. Ren X.; Ustiyan V.; Pradhan A.; Cai Y.; Havrilak JA.; Bolte CS.; Shannon JM.; 
Kalin TV.; Kalinichenko VV. FOXF1 transcription factor is required for formation of embryonic vasculature by regulating VEGF signaling in endothelial cells, Circ Res, 2014, 115(8):709-20. DOI: 10.1161/CIRCRESAHA.115.304382

19. Tiozzo C.; Carraro G.; AI Alam D.; Baptista S.; Danopoulos S.; Li A.; Lavarreda-Pearce M.; Li C.; De Langhe S.; Chan B.; Borok Z.; Bellusci S.; Minoo P. Mesodermal Pten inactivation leads to alveolar capillary dysplasia-like phenotype, J Clin Invest, 2012, 122(11):3862-72. DOI: 10.1172/JCI61334

20. Langston C.; Kida K.; Reed M.; Thurlbeck WM. Human-Lung Growth in Late Gestation and in the Neonate. Am Rev Respir Dis, 1984, 129(4): 607-13.

21. Parker RA.; Lindstrom DP.; Cotton RB. Evidence from twin study implies possible genetic susceptibility to bronchopulmonary dysplasia, Semin Perinatol, 1996, 20(3):2069. DOI: 10.1016/S0146-0005(96)80049-8

22. Bhandari V.; Bizzarro MJ.; Shetty A.; Zhong X.; Page GP.; Zhang H.; Ment LR.; Gruen JR. Neonatal Genetics Study Group. Familial and genetic susceptibility to major neonatal morbidities in preterm twins, Pediatrics, 2006, 117(6):1901-6. DOI: 10.1542/peds.2005-1414

23. Lavoie PM.; Pham C.; Jang KL. Heritability of bronchopulmonary dysplasia, defined according to the consensus statement of the national institutes of health. Pediatrics, 2008, 122(3):479-85. DOI: 10.1542/peds.2007-2313

24. Ryckman KK.; Dagle JM.; Kelsey K.; Momany AM.; Murray JC. Genetic associations of surfactant protein $\mathrm{D}$ and angiotensin-converting enzyme with lung disease in preterm neonates, J Perinatol, 2012, 32(5):349-55. DOI: 10.1038/jp.2011.104

25. Mailaparambil B.; Krueger M.; Heizmann U.; Schlegel K.; Heinze J.; Heinzmann A. Genetic and epidemiological risk factors in the development of bronchopulmonary dysplasia, Dis Markers, 2010, 29(1), 1-9. DOI: $10.1155 / 2010 / 925940$
26. Giusti B.; Vestrini A.; Poggi C.; Magi A.; Pasquini E.; Abbate R.; Dani C. Genetic polymorphisms of antioxidant enzymes as risk factors for oxidative stress-associated complications in preterm infants. Free Radic Res, 2012, 46(9), 1130-9. DOI: $\underline{10.3109 / 10715762.2012 .692787}$

27. Lavoie PM.; Ladd M.; Hirschfeld AF.; Huusko J.; Mahlman M.; Speert DP.; Hallman M.; Lacaze- Masmonteil T.; Turvey SE. Influence of common nonsynonymous Toll-like receptor 4 polymorphisms on bronchopulmonary dysplasia and prematurity in human infants, PLoS One, 2012, 7(2), e31351. DOI: 10.1371/journal.pone.0031351

28. Sampath V.; Garland JS.; Le M.; Patel AL.; Konduri GG.; Cohen JD.; Simpson PM.; Hines RN. A TLR5 (g.1174C > T) variant that encodes a stop codon (R392X) is associated with bronchopulmonary dysplasia, Pediatr Pulmonol, 2012, 47(5), 460-8. DOI: 10.1002/ppul.21568

29. Sun H.; Choo-Wing R.; Fan J.; Leng L.; Syed MA.; Hare AA.; Jorgensen WL.; Bucala R.; Bhandari V.. Small molecular modulation of macrophage migration inhibitory factor in the hyperoxia-induced mouse model of bronchopulmonary dysplasia, Respir Res, 2013, 28;14:27.

30. Prencipe G.; Auriti C.; Inglese R.; Devito R.; Ronchetti MP.; Seganti G.; Rava L.; Orzalesi M.; De BF. A polymorphism in the macrophage migration inhibitory factor promoter is associated with bronchopulmonary dysplasia, Pediatr Res, 2011, 69(2), 142-7. DOI: 10.1203/PDR.0b013e3182042496

31. Floros J.; Londono D.; Gordon D.; Silveyra P.; Diangelo SL.; Viscardi RM.; Worthen GS.; Shenberger J.; Wang G.; Lin Z.; Thomas NJ. IL-18R1 and IL-18RAP SNPs may be associated with bronchopulmonary dysplasia in African-American infants, Pediatr Res, 2012, 71(1), 107-14. DOI: 10.1038/pr.2011.14

32. Krueger M.; Heinzmann A.; Mailaparambil B.; Hartel C.; Gopel W. Polymorphisms of interleukin 18 in the genetics of preterm 
birth and bronchopulmonary dysplasia, Arch Dis Child Fetal Neonatal Ed, 2011, 96(4), F299-300. DOI: 10.1136/adc.2009.174862

33. Hadchouel A.; Decobert F.; FrancoMontoya ML.; Halphen I.; Jarreau PH.; Boucherat O.; Martin E.; Benachi A.; Amselem S.; Danan C.; Delacourt C. Matrix metalloproteinase gene polymorphisms and bronchopulmonary dysplasia: identification of MMP16 as a new player in lung development, PLoS One, 2008, 3(9), e3188. DOI: 10.1371/journal.pone.0003188

34. Concolino P.; Capoluongo E.; Santonocito C.; Vento G.; Tana M.; Romagnoli C.; Zuppi C.; Ameglio F.; Brancaccio A.; Sciandra F. Genetic analysis of the dystroglycan gene in bronchopulmonary dysplasia affected premature newborns, Clin Chim Acta, 2007, 378(1-2), 164-7. DOI: $\underline{10.1016 / j . c c a .2006 .11 .016}$

35. Hilgendorff A.; Heidinger K.; Pfeiffer A.; Bohnert A.; Konig IR.; Ziegler A.; Merz C.; Frey G.; Chakraborty T.; Gortner L.; Bein G. Association of polymorphisms in the mannose-binding lectin gene and pulmonary morbidity in preterm infants, Genes Immun, 2007, 8(8), 671-7. DOI: 10.1038/sj.gene.6364432

36. Kurland G.; Deterding RR.; Hagood JS.; Young LR.; Brody AS.; Castile RG.; Dell S.; Fan LL.; Hamvas A.; Hilman BC.; Langston C.; Nogee LM.; Redding GJ. American Thoracic Society Committee on Childhood Interstitial Lung Disease (chILD) and the chILD Research Network. An official American Thoracic Society clinical practice guideline: classification, evaluation, and management of childhood interstitial lung disease in infancy, Am J Respir Crit Care Med, 2013, 188(3), 376-94. DOI: 10.1164/rccm.201305-0923ST

37. Somaschini M.; Nogee LM.; Sassi I.; Danhaive O.; Presi S.; Boldrini R.; Montrasio C.; Ferrari M.; Wert SE.; Carrera P. Unexplained neonatal respiratory distress due to congenital surfactant deficiency, J Pediatr. 2007, 150(6),649-53, 653.e1.

38. Tredano M.; Cooper DN.; Stuhrmann M.; Christodoulou J.; Chuzhanova NA.; Roudot-
Thoraval F.; Boëlle PY.; Elion J.; Jeanpierre M.; Feingold J.; Couderc R.; Bahuau M. Origin of the prevalent SFTPB indel g.1549C > GAA (121ins2) mutation causing surfactant protein B (SP-B) deficiency, Am J Med Genet A, 2006, 140(1), 62-9.

39. Dunbar AE $3^{\text {rd }}$; Wert SE.; Ikegami M.; Whitsett JA.; Hamvas A.; White FV.; Piedboeuf B.; Jobin C.; Guttentag S.; Nogee LM. Prolonged survival in hereditary surfactant protein B (SP-B) deficiency associated with a novel splicing mutation, Pediatr Res, 2000, 48(3), 275-82. DOI: 10.1203/00006450-200009000-00003

40. Nogee LM.; Dunbar AE $3^{\text {rd }}$; Wert SE.; Askin F.; Hamvas A.; Whitsett JA. A mutation in the surfactant protein $\mathrm{C}$ gene associated with familial interstitial lung disease, N Engl J Med, 2001, 344(8), 573-9. DOI: 10.1056/NEJM200102223440805

41. Soraisham AS.; Tierney AJ.; Amin HJ. Neonatal respiratory failure associated with mutation in the surfactant protein $\mathrm{C}$ gene. $\mathrm{J}$ Perinatol, 2006, 26(1), 67-70. DOI: 10.1038/sj.jp.7211417

42. Abou Taam R.; Jaubert F.; Emond S.; Le Bourgeois M.; Epaud R.; Karila C.; Feldmann D.; Scheinmann P.; de Blic J. Familial inter- stitial disease with I73T mutation: A mid- and long-term study, Pediatr Pulmonol, 2009, 44(2), 167-75. DOI: $10.1002 / \mathrm{ppul} .20970$

43. Cameron HS.; Somaschini M.; Carrera P.; Hamvas A.; Whitsett JA.; Wert SE.; Deutsch G.; Nogee LM. A common mutation in the sur- factant protein $\mathrm{C}$ gene associated with lung disease, J Pediatr, 2005, 146(3), 370-5. DOI: 10.1016/j.jpeds.2004.10.028

44. Guillot L.; Epaud R.; Thouvenin G.; Jonard L.; Mohsni A.; Couderc R.; Counil F.; de Blic J.; Taam RA.; Le Bourgeois M.; Reix P.; Flamein F.; Clement A.; Feldmann D. New surfactant protein $C$ gene mutations associated with diffuse lung disease, $\mathrm{J}$ Med Genet, 2009, 46(7), 490-4. DOI: 10.1136/jmg.2009.066829

45. Bullard JE.; Nogee LM. Heterozygosity for ABCA3 mutations modifies the severity of 
lung disease associated with a surfactant protein C gene (SFTPC) mutation, Pediatr Res, 2007, 62(2), 176-9. DOI: 10.1203/PDR.0b013e3180a72588

46. Citti A.; Peca D.; Petrini S.; Cutrera R.; Biban P.; Haass C.; Boldrini R.; Danhaive O. Ultrastructural characterization of genetic diffuse lung diseases in infants and children: a cohort study and review, Ultrastruct Pathol, 2013, 37(5), 356-65. DOI: 10.3109/01913123.2013.811454

47. Wambach JA.; Wegner DJ.; Depass K.; Heins H.; Druley TE.; Mitra RD.; An P.; Zhang Q.; Nogee LM.; Cole FS.; Hamvas A. Single ABCA3 mutations \&\& increase risk for neonatal respiratory distress syndrome, Pediatrics, 2012, 130(6), e1575-82.

48. Bullard JE.; Wert SE.; Whitsett JA.; Dean M.; Nogee LM.. ABCA3 mutations associated with pediatric interstitial lung disease, Am J Respir Crit Care Med, 2005, 172(8):1026-31.

DOI:

10.1164/rccm.200503-504OC

49. Hallik M.; Annilo T.; Ilmoja ML.. Different course of lung disease in two siblings with novel ABCA3 mutations, Eur J Pediatr, 2014, 173(12):1553-6. DOI: 10.1007/s00431-013-2087-3

50. Kitazawa H.; Moriya K.; Niizuma H.; Kawano K.; Saito-Nanjo Y.; Uchiyama T.; Rikiishi T.; Sasahara Y.; Sakamoto O.; Setoguchi Y.; Kure S. Interstitial lung disease in two brothers with novel compound heterozygous ABCA3 mutations, Eur J Pediatr, 2013, 172(7), 953-7. DOI: $\underline{10.1007 / \mathrm{s} 00431-013-1977-8}$

51. Wambach JA.; Casey AM.; Fishman MP.; Wegner DJ.; Wert SE.; Cole FS.; Hamvas A.; Nogee LM. Genotype-phenotype correlations for infants and children with ABCA3 deficiency. Am J Respir Crit Care Med, 2014 Jun 15;189(12):1538-43. DOI: 10.1164/rccm.201402-0342OC

52. Kaltenborn E.; Kern S.; Frixel S.; Fragnet L.; Conzelmann KK.; Zarbock R.; Griese M. Respiratory syncytial virus potentiates ABCA3 mutation-induced loss of lung epithelial cell differentiation, Hum Mol Genet, 2012, 21(12), 2793-806. DOI: 10.1093/hmg/dds107

53. Krude H.; Schütz B.; Biebermann H.; von Moers A.; Schnabel D.; Neitzel H.; Tönnies H.; Weise D.; Lafferty A.; Schwarz S.; DeFelice M.; von Deimling A.; van Landeghem F.; DiLauro R.; Grüters A. Choreoathetosis, hypothyroidism, and pulmonary alterations due to human NKX21 haploinsufficiency, J Clin Invest, 2002, 109(4), 475-80. DOI: 10.1172/JCI0214341

54. Carré A.; Szinnai G.; Castanet M.; SuraTrueba S.; Tron E.; Broutin-L'Hermite I.; Barat P.; Goizet C.; Lacombe D.; Moutard ML.; Raybaud C.; Raynaud-Ravni C.; Romana S.; Ythier H.; Léger J.; Polak M. Five new TTF1/NKX2.1 mutations in brainlung-thyroid syndrome: rescue by PAX8 synergism in one case, Hum Mol Genet, 2009, 18(12), 2266-76. DOI: 10.1093/hmg/ddp162

55. Hamvas A.; Deterding RR.; Wert SE.; White FV.; Dishop MK.; Alfano DN.; Halbower AC.; Planer B.; Stephan MJ.; Uchida DA.; Williames LD.; Rosenfeld JA.; Lebel RR.; Young LR.; Cole FS.; Nogee LM.. Heterogeneous pulmonary phenotypes associated with mutations in the thyroid transcription factor gene NKX2-1, Chest, 2013, 144(3): 794-804. DOI: $10.1378 /$ chest.12-2502

56. Young LR, Deutsch GH, Bokulic RE, Brody AS, Nogee LM. A mutation in TTF1/NKX2.1 is associated with familial neuroendocrine cell hyperplasia of infancy. Chest. 2013 Oct;144(4):1199-206. DOI: 10.1378/chest.13-0811

57. Trapnell BC.; Whitsett JA. GM-CSF regulates pulmonary surfactant homeostasis and alveolar macrophage-mediated innate host defense. Annu Rev Physiol, 2002, 64:775-802.

10.1146/annurev.physiol.64.090601.113847

58. Trapnell BC.; Whitsett JA.; Nakata K. Pulmonary alveolar proteinosis, N Engl J Med, 2003, 349(26), 2527-39. DOI: 10.1056/NEJMra023226

59. Martinez-Moczygemba M.; Doan ML.; Elidemir O.; Fan LL.; Cheung SW.; Lei JT.; Moore JP.; Tavana G.; Lewis LR.; Zhu Y.; 
Muzny DM.; Gibbs RA.; Huston DP. Pulmonary alveolar proteinosis caused by deletion of the GM-CSFRalpha gene in the $\mathrm{X}$ chromosome pseudoautosomal region 1, J Exp Med, 2008, 205(12), 2711-6. DOI: 10.1084/jem.20080759

60. Suzuki T.; Arumugam P.; Sakagami T.; Lachmann N.; Chalk C.; Sallese A.; Abe S.; Trapnell C.; Carey B.; Moritz T.; Malik P.; Lutzko C.; Wood RE.; Trapnell BC. Pulmonary macrophage transplantation therapy, Nature, 2014, 514(7523), 450-454. DOI: 10.1038/nature13807

61. Canakis AM.; Cutz E.; Manson D.; O'Brodovich H. Pulmonary interstitial glycogenosis: a new variant of neonatal interstitial lung disease, Am J Respir Crit Care Med, 2002, 165(11), 1557-65. DOI: $\underline{10.1164 / \mathrm{rccm} .2105139}$

62. Langston C.; Dishop MK. Diffuse lung disease in infancy: a proposed classification applied to 259 diagnostic biopsies, Pediatr Dev Pathol, 2009, 12(6), 421-37. DOI: 10.2350/08-11-0559.1

63. Ross MK.; Ellis LS.; Bird LM.; Hagood JS. Pulmonary Interstitial Glycogenosis in a Patient Ultimately Diagnosed With Noonan Syndrome, Pediatr Pulmonol, 2014, 49(5),
508-11. DOI: 10.1002/ppul.22871

64. Becroft DM.. adenovirus and bronchial obliterans, J Clin Pathol, 1971, 24(1): 72-82. DOI: $10.1136 /$ jcp.24.1.72

65. Kurland G.; Michelson P. Bronchiolitis obliterans in children, Pediatr Pulmonol, 2005, 39(3), 193-208. DOI: 10.1002/ppul.20145

66. Kim CK.; Kim SW.; Kim JS.; Koh YY.; Cohen AH.; Deterding RR.; White CW. Bronchiolitis obliterans in the 1990s in Korea and the United States, Chest, 2001, 120(4), 1101-6. DOI: 10.1378/chest.120.4.1101

67. Teper AM.; Marcos CY.; Theiler G.; Colom AJ.; Fainboim L. Association between HLA and the incidence of Bronchiolitis Obliterans in Argentina, Am J Respir Crit Care Med, 2004, 169(Suppl), A382.

68. Walter JN.; Fan LL.; Bag R.; Zhang H.; Doan M.; Mallory GB.; Elidemir O. Serum KL-6 as a marker for bronchiolitis obliterans after lung transplantation, Transplantation, 2006, 82(5), 709-11. DOI: 10.1097/01.tp.0000234952.46013.df 